\title{
Concurrentiekracht, productiviteit en human capital : een vergelijking tussen Nederland en Duitsland
}

Citation for published version (APA):

Cörvers, F., de Grip, A., \& Orbon, J-P. (1995). Concurrentiekracht, productiviteit en human capital : een vergelijking tussen Nederland en Duitsland. Researchcentrum voor Onderwijs en Arbeidsmarkt, Faculteit der Economische Wetenschappen. ROA Research Memoranda No. 2 https://doi.org/10.26481/umaror.1995002

Document status and date:

Published: 01/01/1995

DOI:

10.26481/umaror.1995002

Document Version:

Publisher's PDF, also known as Version of record

\section{Please check the document version of this publication:}

- A submitted manuscript is the version of the article upon submission and before peer-review. There can be important differences between the submitted version and the official published version of record.

People interested in the research are advised to contact the author for the final version of the publication, or visit the DOI to the publisher's website.

- The final author version and the galley proof are versions of the publication after peer review.

- The final published version features the final layout of the paper including the volume, issue and page numbers.

Link to publication

\footnotetext{
General rights rights.

- You may freely distribute the URL identifying the publication in the public portal. please follow below link for the End User Agreement:

www.umlib.nl/taverne-license

Take down policy

If you believe that this document breaches copyright please contact us at:

repository@maastrichtuniversity.nl

providing details and we will investigate your claim.
}

Copyright and moral rights for the publications made accessible in the public portal are retained by the authors and/or other copyright owners and it is a condition of accessing publications that users recognise and abide by the legal requirements associated with these

- Users may download and print one copy of any publication from the public portal for the purpose of private study or research.

- You may not further distribute the material or use it for any profit-making activity or commercial gain

If the publication is distributed under the terms of Article $25 \mathrm{fa}$ of the Dutch Copyright Act, indicated by the "Taverne" license above, 
Concurrentiekracht, produktiviteit en human capital: een vergelijking tussen Nederland en Duitsland

Frank Cörvers, Andries de Grip en Jean-Paul Orbon*

ROA-RM-1995/2

Researchcentrum voor Onderwijs en Arbeidsmarkt

Faculteit der Economische Wetenschappen

Rijksuniversiteit Limburg

Maastricht, februari 1995 


\section{CIP-GEGEVENS KONINKLIJKE BIBLIOTHEEK, DEN HAAG}

\section{Cörvers, Frank}

Concurrentiekracht, produktiviteit en human capital: een vergelijking tussen Nederland en Duitsland / Frank Cörvers, Andries de Grip en Jean-Paul Orbon. - Maastricht : Researchcentrum voor Onderwijs en Arbeidsmarkt, Faculteit der Economische Wetenschappen, Rijksuniversiteit Limburg. - (ROA-RM-1995/2)

Met lit. opg.

ISBN 90-5321-156-X

Trefw.: arbeidsproduktiviteit ; Nederland / arbeidsproduktiviteit ; Duitsland. 
Inhoudsopgave

Pagina

Samenvatting

1 Inleiding 1

2 Human capital en arbeidsproduktiviteit 3

3 Arbeidsproduktiviteit en opleidingen van Nederlandse en Duitse bedrijfssectoren 9

4 De betekenis van human capital voor de arbeidsproduktiviteit 14

5 Besluit 19

Literatuur $\quad 21$ 



\section{Samenvatting}

In dit paper wordt een overzicht gegeven van de effecten van middelbaar onderwijs, hoger onderwijs en training op de produktiviteit van werknemers. Indien Nederlandse en Duitse industriële bedrijfssectoren met elkaar worden vergeleken op basis van hun gemiddelde arbeidsproduktiviteit, dan blijkt dat Nederland in de meeste sectoren een concurrentievoordeel heeft. Daarentegen blijft het gemiddelde opleidingsniveau van de Nederlandse werknemers achter bij dat van Duitse werknemers. Dit laatste is niet alleen te wijten aan de relatief kortere nominale opleidingsduur van middelbaar en hoger opgeleiden in Nederland, maar vooral ook aan het relatief kleine aandeel van middelbaar en hoger opgeleide werknemers in de totale werkgelegenheid in de Nederlandse bedrijfssectoren. Op basis van de schattingen van het empirische model in dit paper blijkt dat de kapitaalintensiteit een belangrijke factor is voor de relatief sterke concurrentiepositie van Nederlandse ten opzichte van Duitse bedrijfssectoren. Bovendien zou de grotere trainingsparticipatie van Nederlandse ten opzichte van Duitse werknemers de relatief hoge arbeidsproduktiviteit in Nederland kunnen verklaren. De trainingsparticipatie kon echter niet als verklarende variabele worden opgenomen. Uit de empirische resultaten kan geconcludeerd worden dat de Duitse concurrentiekracht vooral gebaseerd is op de inzet van menselijk kapitaal in het produktieproces, terwijl de Nederlandse concurrentiekracht gebaseerd is op de inzet van fysiek kapitaal en lager geschoolde arbeid.

Frank Cörvers en Andries de Grip zijn werkzaam bij het Researchcentrum voor Onderwijs en Arbeidsmarkt, Maastricht. Jean-Paul Orbon is werkzaam bij een expertisebureau voor verzekeringen in Milaan. De auteurs danken Lex Borghans en Hans Heijke voor hun waardevolle suggesties en Jeroen Hoevenberg en Aad van Mourik voor hun hulp bij de aanlevering van data. 



\section{Inleiding}

Onder het adagium 'Concurreren met kennis' lanceerde het Ministerie van Economische Zaken (1993) haar visie op het Nederlandse technologiebeleid. Het besef van het cruciale belang van de produktiefactor menselijk kapitaal is tegenwoordig in beleidskringen een vanzelfsprekendheid (zie bv. OECD, 1986). Ook binnen Porter's raamwerk (1990) om de internationale concurrentiepositie van een land te analyseren, neemt het beschikbare human capital een centrale plaats in (zie ook Jacobs, cs., 1990).

De gedachte dat kennis bijdraagt aan de concurrentiekracht van de economie is terug te voeren op een tweetal economische theorieën: de Ricardiaanse handelstheorie en de human capital-theorie. De Ricardiaanse handelstheorie biedt aanknopingspunten voor de hypothese dat de concurrentiekracht van een land versterkt wordt door te investeren in kennis. De produktietechnologie bepaalt in de Ricardiaanse handelstheorie de comparatieve voordelen (de relatieve loonkosten en de relatieve arbeidsproduktiviteit) van een land. Het begrip produktietechnologie kan echter breed ingevuld worden. In door de Ricardiaanse handelstheorie geïnspireerde neo-technologie modellen vinden de verschillen in produktietechnologie hun oorzaak in de verschillen in technologische kennis. Technologische kennis is in deze modellen de belangrijkste factor voor de concurrentiekracht van bedrijfssectoren (zie bv. Dosi, Pavitt en Soete, 1990). Hierbij moet echter worden aangetekend dat verschillen in de voorraad technologische kennis slechts voor de korte termijn van belang zijn, vanwege de hoge diffusiesnelheid van nieuwe technologieën in geïndustrialiseerde landen. ${ }^{1}$ Het onderwijssysteem zou daarentegen bij uitstek een factor kunnen zijn die structureel bijdraagt aan de kennisstructuur en daarmee de concurrentiekracht van een land. Door een goed onderwijssysteem kan een land comparatieve voordelen opbouwen in de produktie van goederen die een hoge produktiviteit combineren met een hoog loonniveau, waardoor de welvaart van het land veilig gesteld wordt (Ministerie van Economische Zaken, 1990). ${ }^{2}$

De human capital theorie biedt de mogelijkheid om een nadere invulling te geven aan het begrip produktietechnologie door het benadrukken van het belang van onderwijs en training voor de arbeidsproduktiviteit. De gebruikte produktietechnologie hangt namelijk

1. Zie hierover bijvoorbeeld Dollar (1993). Het gaat in deze modellen eigenlijk om de groeiverschillen in de voorraad technologische kennis.

2. Zie Mankiw, Romer en Weil (1992) voor de relevantie van human capital in een aangepast macro-economisch groeimodel van Solow. In dit model wordt de inkomensgroei per hoofd van de bevolking niet alleen verklaard uit de bevolkingsgroei en de accumulatie van fysiek kapitaal als in Solow's standaardmodel, maar ook uit de accumulatie van menselijk kapitaal (door onderwijs). 
voor een belangrijk deel samen met de kwalificaties van de beroepsbevolking. ${ }^{3}$ Met name bij de introductie van nieuwe technologieën is de arbeidsinzet van hoger opgeleiden van groot belang, omdat in een dergelijke situatie grote produktiviteitsstijgingen geboekt kunnen worden (zie bv. Bartel en Lichtenberg, 1987). Overigens leidt investeren in onderwijs en training ook in laag-technologische sectoren tot produktiviteitsstijgingen (zie bv. Steedman en Wagner, 1987).

In het algemeen kan gesteld worden dat menselijk kapitaal in de vorm van geaccumuleerde kennis en vaardigheden verkregen door onderwijs en training op drie manieren een belangrijke rol speelt in het produktieproces. Ten eerste is human capital een produktiefactor naast de traditionele produktiefactoren fysiek kapitaal en arbeid. Door te differentiëren naar het opleidingsniveau van werkenden kan rekening worden gehouden met human capital als produktiefactor van een bedrijf of een bedrijfssector (zie bv. Broer en Jansen, 1989 en Hebbink, 1992), waarbij geldt dat werkenden met een hoger opleidingsniveau produktiever zijn. Ten tweede is human capital van cruciaal belang voor de diffusie van nieuwe technologieën (zie bv. Nelson en Phelps, 1966 en Bartel en Lichtenberg, 1987). Om produktiviteitsstijgingen te boeken met het introduceren van nieuwe technologieën zijn goed opgeleide werknemers onmisbaar. Ten derde is human capital een belangrijke inputfactor bij research en development (R\&D), hetgeen vooral in de endogene groeitheorie wordt benadrukt (zie bv. Van Cayseele, 1990, Romer, 1990 en Den Butter en Wollmer, 1993). Bijna $90 \%$ van de totale R\&D uitgaven in zowel Nederland als Duitsland bestaat uit lopende kosten, d.w.z. arbeidskosten van veelal hooggeschoolde werknemers (NOWT, 1994).

In dit paper staat de vraag centraal in welke mate investeringen in human capital kunnen bijdragen aan de verbetering van de concurrentiekracht van bedrijfssectoren. De analyse zal daarbij worden toegespitst op een vergelijking van de concurrentiekracht en het aanwezige human capital van Nederlandse en Duitse bedrijfssectoren. De vergelijking met Duitsland is een belangrijke maatstaf voor het in beeld brengen van de internationale concurrentiepositie van het Nederlandse bedrijfsleven. Duitsland is immers niet alleen een belangrijk afzetgebied voor Nederland, maar ook een belangrijke concurrent van Nederland op de markten binnen en buiten de Europese Unie. Getoetst zal worden of de arbeidsproduktiviteit in de verschillende Nederlandse en Duitse bedrijfssectoren afhankelijk is van de investeringen in onderwijs en training. Vanzelfsprekend wordt in dit model de arbeidsproduktiviteit mede bepaald door de produktiefactor fysiek kapitaal.

3. Zie hiervoor bijvoorbeeld de empirische studies van Daly, Hitchens en Wagner (1985) en Steedman en Wagner (1987) voor een vergelijking van de Duitse en Britse produktiviteit in respectievelijk de metaal- en de meubel-industrie. 
De verdere opbouw van dit paper is als volgt. In paragraaf 2 zal nader worden ingegaan op de wijze waarop human capital bijdraagt aan de arbeidsproduktiviteit, waarbij een onderscheid wordt gemaakt tussen vier effecten: het werknemerseffect, het allocatie-effect, het diffusie-effect en het research-effect. Deze effecten zullen worden gerelateerd aan het opleidingsniveau van de werkenden (lager, middelbaar en hoger) en de investeringen in training. In paragraaf 3 worden de arbeidsproduktiviteit van Duitsland en Nederland met elkaar vergeleken. Bovendien wordt een beeld geschetst van de verschillen in opleidingsniveau en trainingsparticipatie van Duitse en Nederlandse bedrijfssectoren. In paragraaf 4 wordt het belang van investeringen in human capital voor de arbeidsproduktiviteit in Duitse en Nederlandse bedrijfssectoren in een empirisch model getoetst. ${ }^{4}$ Ten slotte volgen in paragraaf 5 enkele concluderende opmerkingen.

\section{Human capital en arbeidsproduktiviteit}

\section{Investeringen in onderwijs}

Volgens de human capital theorie bestaat er een causaal verband tussen het opleidingsniveau van werknemers en de hoogte van hun loon (zie bv. Becker, 1975 en Mincer, 1974). Doordat individuen investeren in onderwijs en training aan het begin van hun leven of tijdens hun loopbaan, zullen zij later de kosten van deze investeringen terugverdienen door een hogere produktiviteit en een navenant hoger loon (Mincer, 1974). De kosten van onderwijs in het initiële onderwijs worden gedragen door enerzijds het individu zelf (directe kosten als lesgelden, reiskosten e.d. en indirecte 'alternatieve' kosten door het niet verrichten van werk). Anderzijds draagt ook de overheid in belangrijke mate bij in de financiering van het onderwijssysteem. De kosten en opbrengsten van de training van werkenden worden in de praktijk doorgaans door werknemers en werkgevers gedeeld (zie Hashimoto, 1981, Bishop, 1991 en Hill, 1991). De opbrengsten van de overheid en de werkgevers bestaan uit respectievelijk de hogere belastinginkomsten en de stijging van de arbeidsproduktiviteit van de werknemers. ${ }^{5}$

De human capital theorie wordt meestal getoetst op basis van het leeftijd-inkomstenverloop van werknemers met een verschillend opleidingsniveau. (zie bv. Blaug, 1970, Mincer, 1974

4. Hoewel in dit paper vooral de opbrengsten van investeringen in kapitaal (fysiek of menselijk) worden beschouwd aan de hand van het effect op de arbeidsproduktiviteit, zijn de kosten van deze investeringen niet meegenomen in de analyse. Bovendien zijn andere vormen van investeringen in human capital dan initieel onderwijs en formele trainingsactiviteiten, bv. ervaring, niet meegenomen in de empirische analyse.

5. Zie voor een recente Nederlandse studie Gelderblom en De Koning (1994). 
en Pencavel, 1991) Uit dergelijke onderzoeken blijkt dat, bij gelijke leeftijd, de lonen van hoger opgeleiden in de meeste gevallen hoger zijn dan die van lager opgeleiden. Het individueel rendement van een investering in onderwijs kan worden berekend met de netto contante waarde methode. In deze methode worden de kosten van onderwijs en de toekomstige opbrengsten verdisconteerd. Wat echter niet uit dergelijk onderzoek blijkt is of het verband tussen het aantal jaren onderwijs en de hoogte van het loon causaal is (zie Blaug, 1985 en Woodhall, 1987). Bovendien is er relatief weinig onderzoek gedaan waarin de relatie tussen onderwijs en produktiviteit (i.p.v. het loon) direct wordt geanalyseerd.

Geïnspireerd door de human capital theorie heeft Welch (1970) geprobeerd de veronderstelde causaliteit tussen onderwijs en produktiviteit theoretisch beter te onderbouwen. ${ }^{6} \mathrm{Hij}$ maakt daarbij onderscheid tussen twee effecten van onderwijs die de arbeidsproduktiviteit kunnen vergroten. Ten eerste is het werknemers-effect ('worker effect'), dat aangeeft dat een hoger oplaidingsniveau van werknemers resulteert in een stijging van de marginale fysieke arbeidsproduktiviteit bij de produktie van één bepaald goed. Hierbij blijft de inzet van de overige produktiefactoren constant. Werknemers zijn door hun hogere opleidingsniveau in staat een groter aantal produkten per tijdseenheid te produceren. Met andere woorden, human capital vergroot de produktiviteit bij een gelijkblijvend aantal werknemers. Volgens Welch (1970) is de mate waarin het werknemers-effect optreedt afhankelijk van de complexiteit van het fysieke produktieproces. Des te complexer het fysieke produktieproces, des te groter het potentiële werknemers-effect. Naarmate werknemers hoger zijn opgeleid, zijn ze beter inzetbaar in complexe produktieprocessen en stijgt hun produktiviteit als gevolg van het werknemers-effect.

Het tweede effect dat Welch (1970) onderscheidt, is het allocatie-effect ('allocative effect'). Dit effect duidt op de grotere efficiëntie waarmee hoger opgeleiden de inzet van de beschikbare produktiefactoren verdelen over de goederen die geproduceerd worden. In tegenstelling tot het werknemers-effect, dat betrekking heeft op een toename in de fysieke produktie van één bepaald goed, gaat het hier om allocatie-beslissingen met betrekking tot meerdere produktiefactoren en te produceren goederen. Ram (1980, p. 366) legt nadruk op het belang van informatie voor betere allocatie-beslissingen en een efficiëntere produktie, en stelt dat onderwijs een belangrijke factor is om die informatie te verwerven en de waarde ervan te vergroten: "Education generally has the effect of lowering the (marginal) costs of acquiring production-related information, and of raising the (marginal) benefits of such information." Ram (1980) voert hierbij aan dat onderwijs de communica-

6. Hoewel Welch (1970) zijn model ook empirisch toetst, is het empirisch gezien moeilijk om de juistheid van de human capital theorie tegenover alternatieve theorieën als de screening theorie vast te stellen (zie bv. Blaug, 1985, en Woodhall, 1987). Zie ook Maglen (1990) voor een kritische evaluatie van onderzoek naar de relatie tussen onderwijs en produktiviteit. 
tieve vaardigheden van werknemers vergroot, de informatiekanalen verbetert, het oordeelsvermogen verbetert en de toepassingsmogelijkheden van informatie vergroot.

Een derde effect van onderwijs op de arbeidsproduktiviteit, het diffusie-effect, wordt door Welch (1970) beschouwd als een afgeleide van het allocatie-effect. Bij het diffusie-effect gaat het met name om het efficiënte gebruik van informatie met betrekking tot technologische vernieuwingen. Het diffusie-effect is gebaseerd op de Nelson-Phelps hypothese dat hoger opgeleide werknemers (inclusief ondernemers) een groter innovatief vermogen hebben en daardoor eerder nieuwe produktietechnieken zullen introduceren dan lager opgeleiden (Nelson en Phelps, 1966). Bovendien kunnen hoger opgeleide werknemers zich sneller aanpassen aan de onzekerheden die gepaard gaan met de nieuw geïntroduceerde technologieën, met andere woorden, ze zullen sneller produktiviteitsstijgingen boeken bij technologische vooruitgang. ${ }^{7}$ Dit resulteert in een grotere toename van de produktiviteit kij diffusie van nieuwe technologieën, indien de inzet van hoger opgeleiden (human capital) in het produktieproces groter is. Zoals in Cörvers (1994a) wordt betoogd, is het vierde effect van onderwijs op de arbeidsproduktiviteit, het research-effect, een afgeleide van het werknemers-effect. Het research-effect heeft namelijk betrekking op de zeer complexe produktieprocessen in research en development (R\&D). De technologische kennis die uit R\&D voortkomt, kan belangrijke produktiviteitsstijgingen teweeg brengen (zie bv. Verspagen, 1993). Deze produktiviteitsstijgingen kunnen alleen worden behaald door de inzet van hoog opgeleide en gespecialiseerde arbeidskrachten in R\&D-activiteiten (Pencavel, 1991).

Empirisch onderzoek met betrekking tot bovengenoemde effecten is vaak toegespitst op de agrarische sector in de Verenigde Staten (zie bv. Huffman, 1977, Ram, 1980 en Wozniak, 1987). Uit dit onderzoek blijkt dat de produktiviteit van hoger opgeleiden hoger ligt omdat zij eerder en efficiënter nieuwe technieken gebruiken, waarmee het bestaan van het diffusie-effect wordt bevestigd. Deze onderzoeken vinden echter geen aanwijzingen voor het werknemerseffect en het allocatie-effect (zonder veranderingen in produktietechnologie). Lockheed (1987) komt in een uitgebreid overzicht van 31 datasets (van landbouwsectoren in ontwikkelingslanden) die in empirische studies gebruikt zijn, tot de conclusie dat de produktiviteitsstijging als gevolg van een hoger onderwijsniveau van boeren alleen aanzienlijk is in agrarische bedrijven die met technologische vooruitgang geconfronteerd worden (diffusie-effect), terwijl in traditionele omstandigheden de produktiviteitsstijging door onderwijs gering is. Andere indicaties voor het diffusie-effect zijn te vinden in Bartel en Lichtenberg (1987) voor 61 industrieën in de Verenigde Staten, en in

7. Zie Bartel en Lichtenberg (1987) voor het verschil tussen de introductie ('adoption') van en aanpassing ('implementation') aan nieuwe technologieën. 
Groot en De Grip (1991) voor 100 lokale bankvestigingen in Nederland.

Bovengenoemde onderzoeken meten echter het opleidingsniveau van werknemers in sectoren of bedrijven op verschillende manieren, zoals het gemiddelde aantal jaren onderwijs van werknemers en het aandeel van werknemers met een bepaald opleidingsniveau, waarbij vaak wordt verondersteld dat de invloed van het opleidingsniveau op de produktiviteit verschilt per functie (bv. management of produktiewerk). In de empirische analyse in dit paper zal echter worden uitgegaan van een indeling in drie opleidingsniveaus, nl. lager, middelbaar en hoger onderwijs, om de invloed van onderwijs op de gemiddelde arbeidsproduktiviteit van bedrijfssectoren na te gaan. Er wordt verondersteld dat middelbaar en hoger opgeleiden een grotere bijdrage leveren aan de gemiddelde produktiviteit dan lager opgeleiden vanwege het werknemers- en het allocatie-effect. Ook zullen middelbaar opgeleiden als gevolg van het diffusie-effect eerder dan lager opgeleiden produktiviteitsstijgingen boeken als de gebruikte produktietechniek verandert, en eerder overgaan tot de introductie van nieuwe, produktiviteitsverhogende produktietechnologieën. Het diffusie-effect is waarschijnlijk nog belangrijker voor hoger opgeleiden, omdat zij vaak als eerste te maken krijgen met de introductie van nieuwe technologieën. ${ }^{8}$ Bovendien zijn hoger opgeleiden relatief vaak werkzaam in complexe produktieprocessen als research en development (het research-effect, zie Berendsen, De Grip en Willems, 1991).

Een onderzoek van Gelderblom en De Koning (1992) geeft echter aan dat er voorzichtigheid geboden is bij de interpretatie van de effecten van onderwijs op produktiviteit. Uit hun onderzoek blijkt dat het aandeel werkenden met minimaal een opleiding op MBO/HAVO/NWO-niveau in het personeelsbestand van bedrijven een positieve invloed heeft op de gemiddelde produktiviteit. Echter, het effect van het aandeel hoog opgeleiden ( $\mathrm{HBO}$ en WO) op de gemiddelde produktiviteit in bedrijven is niet positief maar zelfs significant negatief. ${ }^{9}$ Gelderblom en De Koning (1992) opperen dat het produktiviteitseffect van het aandeel hoger opgeleiden zich mogelijk vertaalt via andere verklarende variabelen die zowel een positieve partiele correlatie hebben met het aandeel hoog opgeleiden (multicollineariteit) $^{10}$ als ook een positieve invloed hebben op de gemiddelde produktiviteit. Deze variabelen zijn bv. de automatiseringsgraad als indicator voor de gebruikte techno-

8. Zie Soete en Verspagen (1993) over de 'voedingsbodemrol' van het onderwijs ten aanzien van de verspreiding van kennis en de diffusie van nieuwe technologie.

9. Daarentegen is het effect van het aandeel hoger opgeleiden op het gemiddelde loon significant positief.

10. Dit probleem kan zich ook voordoen in de empirische analyse in paragraaf 4 . 
logie en de afschrijvingen per werknemer als indicator voor de produktiefactor kapitaal. ${ }^{11}$ De complementariteit tussen onderwijs en technologie is hierboven al besproken, terwijl de complementariteit tussen onderwijs en fysiek kapitaal in vele studies wordt bevestigd (zie voor Nederland bv. Broer en Jansen, 1989 en Hebbink, 1992).

Daly (1986) vindt voor het aandeel hoog geschoolden een positieve invloed op de relatieve arbeidsproduktiviteit in bedrijfssectoren in de Verenigde Staten en Engeland. Daarentegen blijkt het aandeel middelbaar geschoolden een negatieve invloed te hebben op de relatieve arbeidsproduktiviteit. Daly hecht echter niet veel waarde aan het laatstgenoemde resultaat, omdat het te wijten kan zijn aan definitieproblemen bij de vergelijking van de onderwijssystemen voor middelbaar onderwijs in de Verenigde Staten en Engeland. Uit vergelijkende onderzoeken naar produktiviteitsverschillen tussen dezelfde sectoren van Europese landen (waaronder Nederland, Duitsland, Engeland en Frankrijk) lijken juist de aandelen van werknemers met een middelbare opleiding een positieve invloed te hebben op de gemiddelde produktiviteit (CPB, 1993). De relevantie van middelbaar beroepsonderwijs wordt ook sterk benadrukt in diverse studies in Ryan (1991).

\section{Investeringen in training}

De hierboven onderscheiden effecten met betrekking tot de positieve invloed van onderwijs op de arbeidsproduktiviteit gelden gedeeltelijk ook voor de invloed van de training van werkenden op de arbeidsproduktiviteit. Werknemers kunnen tijdens hun loopbaan human capital verwerven door deel te nemen aan formele trainingsprogramma's (cursussen) of door training on-the-job (waaronder learning-by-doing, zie Cörvers, 1994). Door training zijn werknemers beter in staat met complexe produktieprocessen (werknemers-effect) en met informatie (allocatie-effect) om te gaan. Voor zover die informatie betrekking heeft op nieuwe produktietechnologieën, lijkt de deelname van werknemers aan trainingsprogramma's vooral een reactie te zijn op de introductie van nieuwe technologieën (diffusie-effect).

Empirisch onderzoek naar de relatie tussen training en produktiviteit is echter betrekkelijk schaars. Veelal worden loonstijgingen gedurende de loopbaan van werknemers (het leeftijd-inkomsten verloop) als een aanwijzing gezien voor de toename van de arbeidsproduktiviteit en het menselijk kapitaal van werknemers naarmate men meer werkervaring heeft. Barron cs. (1989) meten daarentegen het effect van het aantal uren training van nieuwe werknemers in bedrijven in de Verenigde Staten op de stijging van zowel het loon

11. Ook de negatieve coëfficiënten van dummyvariabelen voor sectoren die relatief veel laag opgeleiden in dienst hebben, dragen ertoe bij dat het verwachte positieve effect van het aandeel hoog opgeleiden op de produktiviteit niet zichtbaar is. 
als de produktiviteit. Produktiviteit wordt daarbij gemeten door de werkgever te vragen naar een produktiviteitsscore, terwijl training wordt gemeten door het aantal uren dat besteed wordt aan cursussen, informele training door bovengeschikten en collega's en observatie en oriëntatie door nieuwe werknemers. Uit dit onderzoek komt naar voren dat ongeveer 30 procent van de werktijd van nieuwe werknemers gedurende de eerste drie maanden wordt besteed aan allerlei vormen van training. Verder komen Barron, Black en Loewenstein (1989) tot de conclusie dat 10 procent meer trainingsuren resulteert in een produktiviteitsstijging van 3 procent en een loonstijging van 1,5 procent. ${ }^{12}$ Groot (1993a) hanteert een soortgelijke methode als in Barron cs. (1989) om de effecten van training op het loon en de produktiviteit in Nederland te onderzoeken. Uit dit onderzoek blijkt dat door het volgen van training de produktiviteit van werknemers met $16 \%$ stijgt, terwijl het loon met $3,7 \%$ stijgt.

Empirische onderzoeken naar produktiviteitsstijgingen op ondernemings- of sectorniveau in plaats van het individuele niveau zijn eveneens schaars: "too much research on the effects of training has been done at the individual level and not enough at the organizational level." (Bartel, 1991, p. 2) Bartel komt tot de conclusie dat de produktiviteit van bedrijven met een relatief lage produktiviteit aanzienlijk kan worden verhoogd, wanneer deze trainingsprogramma's voor hun werknemers beginnen. Voor de bedrijven in de Verenigde Staten die Bartel onderzocht, was de produktiviteitsgroei $17 \%$ hoger dan bij bedrijven die geen trainingsprogramma's hadden.

Voor Nederland blijkt uit het onderzoek van Gelderblom en De Koning (1992) dat het aandeel van het personeel dat een externe cursus heeft gevolgd, een positieve invloed heeft op de produktiviteit van het desbetreffende bedrijf. Het aandeel van het personeel dat een interne cursus heeft gevolgd, blijkt echter geen significant positieve invloed te hebben op de produktiviteit. Dit kan volgens Gelderblom en De Koning (1992) verklaard worden uit het feit dat interne cursussen en on-the-job training substitueerbaar zijn. In hun onderzoek is echter geen variabele opgenomen voor on-the-job training, waardoor het gemeten effect van interne cursussen op de produktiviteit geringer zou kunnen zijn. Overigens kunnen ook initiële scholing en training substitueerbaar zijn. Groot (1993b) vindt echter geen indicaties voor deze hypothese, noch voor de hypothese dat initiële scholing en training complementair zijn. ${ }^{13}$

12. Uit het verschil tussen produktiviteits- en loonstijgingen blijkt dat er sprake is van 'sharing' van kosten en opbrengsten van training (Hashimoto, 1981), waarop we hier niet nader ingaan.

13. Deze laatste hypothese is in feite terug te voeren op Thurow (1975), die stelt dat meer onderwijs de 'trainability' van werknemers vergroot. 
Anderzijds blijkt uit het onderzoek van Groot en De Grip (1991), dat indien er bij bedrijven een grotere vraag naar human capital ontstaat als gevolg van technologische veranderingen, dit human capital niet alleen verkregen wordt door het aantrekken van nieuwkomers die een hoge initiële opleiding hebben gevolgd ('recruteringsoptie'), maar ook door het aanbieden van cursussen aan het personeel ('trainingsoptie'). Training van het eigen personeel blijkt dus een alternatief te zijn voor het aantrekken van beter gekwalificeerd personeel van buiten het bedrijf.

\section{Arbeidsproduktiviteit en opleidingsniveau van Nederlandse en Duitse bedrijfssectoren}

\section{Arbeidsproduktiviteit}

Figuur 1

Relatieve arbeidsproduktiviteit (RAP) van Nederlandse ten opzichte van Duitse bedrijfssectoren, $1989^{*}$

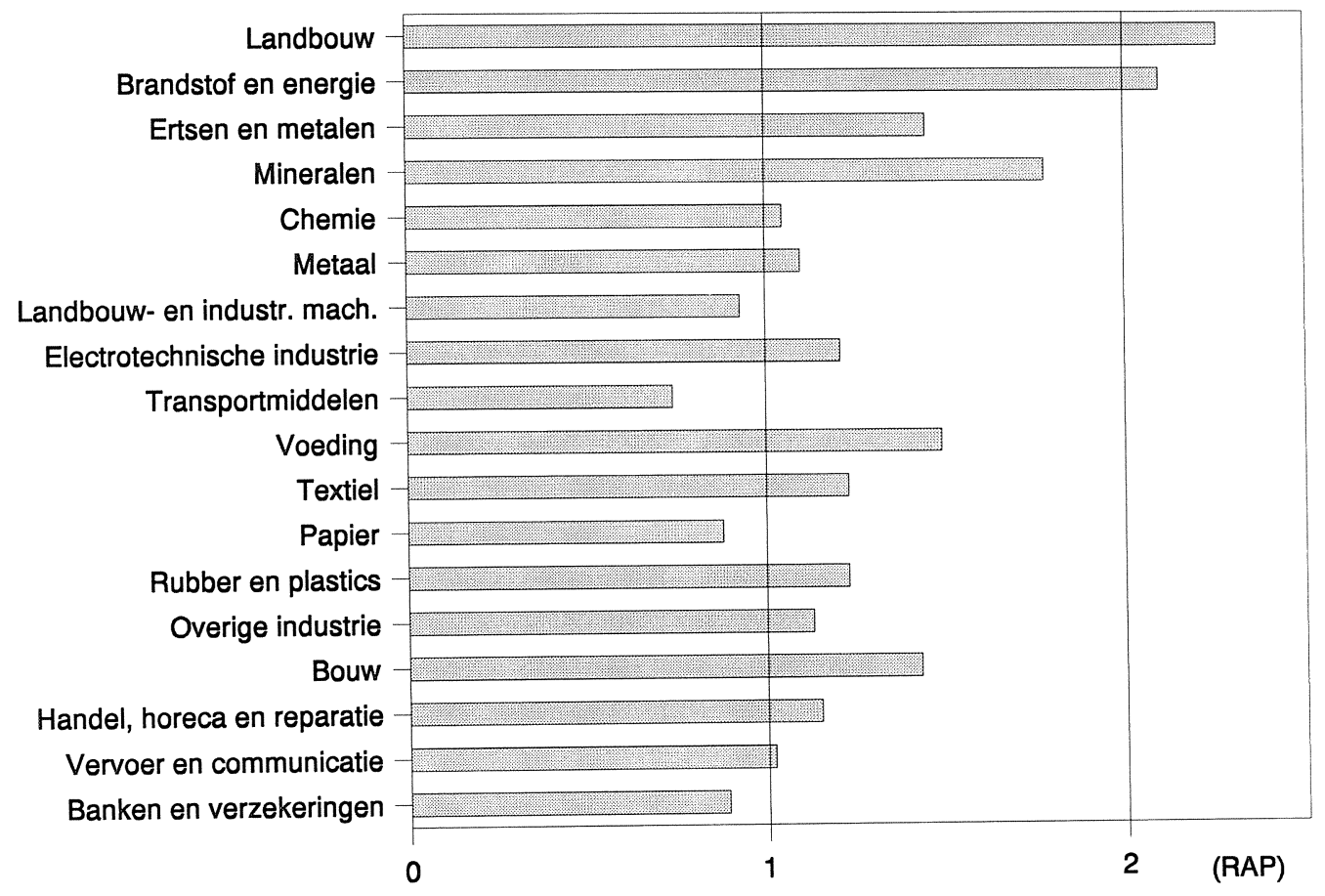

* Relatieve arbeidsproduktiviteit in 1988 voor Overige industrie, Bouw, Vervoer en communicatie, Banken en verzekeringen; Relatieve arbeidsproduktiviteit in 1987 voor Handel, horeca en reparatie

Bron: Eurostat, National Accounts ESA - Detailed Tables by Branch

Om een indruk te krijgen van de arbeidsproduktiviteitsverschillen tussen Nederland en 
Duitsland, wordt in figuur 1 een overzicht gegeven van de relatieve arbeidsproduktiviteit van 18 Nederlandse bedrijfssectoren ten opzichte van dezelfde bedrijfssectoren in Duitsland voor het jaar $1989 .{ }^{14}$ Daarbij is de arbeidsproduktiviteit bepaald door de toegevoegde waarde tegen factorkosten per bedrijfssector (uitgedrukt in ECU's) te delen door het aantal in de sector werkzame personen.

Uit de figuur blijkt dat in maar liefst 14 van de 18 bedrijfssectoren de arbeidsproduktiviteit van de Nederlandse bedrijfssector hoger is dan in dezelfde bedrijfssectoren in Duitsland. ${ }^{15}$ Vooral in de bedrijfssectoren Landbouw, Brandstof en energie, Ertsen en metalen, Mineralen, Voeding en Bouw is de arbeidsproduktiviteit in Nederland veel hoger dan in Duitsland. In vier bedrijfssectoren overtreft daarentegen de arbeidsproduktiviteit in Duitsland die in Nederland: Transportmiddelen, Papier, Banken en verzekeringen en Landbouw- en industriële machines.

\section{Opleidingsniveau}

Om het gemiddelde opleidingsniveau in een bepaalde bedrijfssector tussen Nederland en Duitsland te kunnen vergelijken, moet bij de weging van de aandelen werknemers met een bepaald opleidingsniveau (zie Orbon, 1994), rekening worden gehouden met het feit dat de nominale opleidingsduur van vergelijkbare opleidingstrajecten voor middelbaar en hoger opgeleiden in Duitsland een jaar langer is dan in Nederland. Daarentegen is de nominale opleidingsduur van het opleidingstraject van lager opgeleiden in Nederland twee jaar langer dan in Duitsland (zie Orbon, 1994).

Figuur 2 geeft een overzicht van het gemiddelde opleidingsniveau van werkenden in Nederland en Duitsland in 1990, verbijzonderd naar 19 bedrijfssectoren. Daarbij is uitgegaan van het in beide landen vereiste aantal jaren onderwijs om een bepaald opleidingsniveau te behalen. ${ }^{16}$ Uit de figuur komt naar voren dat in alle bedrijfssectoren de werkenden in Nederland gemiddeld minder onderwijs hebben gevolgd dan hun Duitse collega's. Het verschil in het gemiddeld gevolgde aantal jaren onderwijs is het grootst in de bedrijfssector Overige industrie (3,3 jaar) en het geringst in de bedrijfssector Chemische produkten (1,0 jaar).

14. De bedrijfsindeling is gebaseerd op de NACE-CLIO R25 classificatie van Eurostat. Evenals alle andere gegevens voor Duitsland hebben de gebruikte cijfers hier betrekking op het voormalige West-Duitsland. Zie Orbon (1994) voor een nadere toelichting op de data.

15. Dat wil zeggen dat de relatieve arbeidsproduktiviteit groter is dan 1 (zie ook Van Ark, 1993).

16. Hierbij is alleen gekeken naar het voltooide onderwijs. 
Figuur 2

Gemiddelde opleidingsniveau per bedrijfssector, 1990

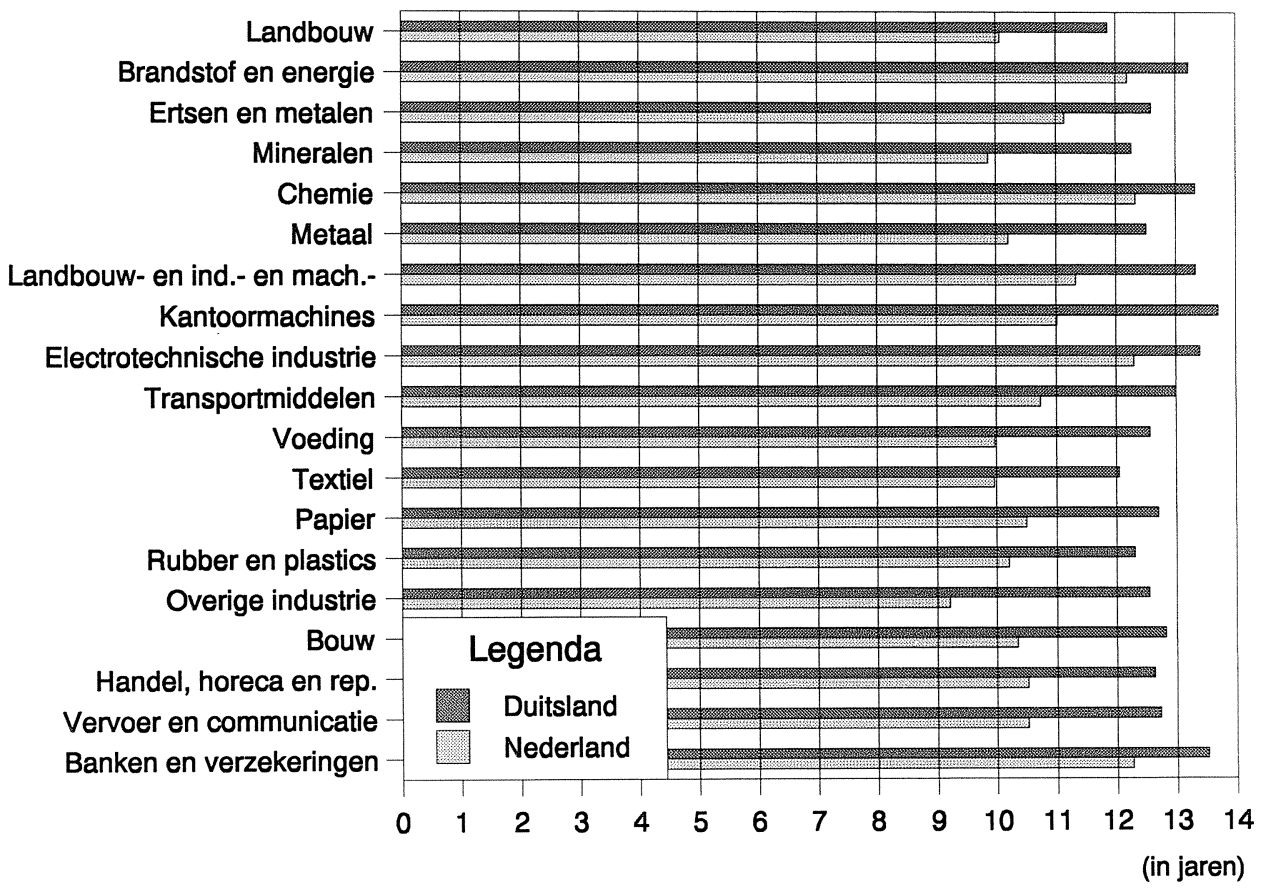

Bron: Eurostat, Labour Force Survey

Uit tabel 1 blijkt dat niet alleen de verschillen in de nominale opleidingsduur voor de diverse opleidingsniveaus verantwoordelijk zijn voor de verschillen in het gemiddelde opleidingsniveau. In het merendeel van de bedrijfssectoren zijn in Nederland relatief minder middelbaar of hoger opgeleiden werkzaam (en dus meer lager opgeleiden). ${ }^{17}$ Het percentage werkenden zonder een middelbare opleiding is in Nederland in maar liefst 16 van de 19 bedrijfssectoren hoger dan in Duitsland. In slechts drie bedrijfssectoren is het percentage werkenden met een middelbare opleiding hoger dan in Duitsland, te weten: Landbouw, Brandstof en energie en Kantoormachines. Het percentage hoger opgeleiden is in Nederland in slechts vijf bedrijfssectoren hoger dan in Duitsland, namelijk: Ertsen en metalen, Mineralen, Chemie, Electrotechniek en Banken en verzekeringen.

17. Werknemers in Nederland die het MBO, het leerlingwezen, de HAVO of het WWO hebben doorlopen, worden tot de middelbaar opgeleiden gerekend. Werknemers in Duitsland die het Fachgymnasium, het Gymnasium, de Fachoberschule, de Berufsfachschule of het leerlingwezen (duale System) hebben doorlopen, worden eveneens tot de middelbaar opgeleiden gerekend. Werknemers met een HBO- of WO-opleiding (in Duitsland Fachhochschule, Hochschule of Universität) worden tot de hoger opgeleiden gerekend (zie Eurostat, 1988). 
Tabel 1

Verschil in opleidingsniveau per bedrijfssector, middelbaar en hoger opgeleiden (percentage Nederland minus percentage Duitsland, 1990*

\begin{tabular}{lcc} 
Bedrijfssector & $\mathrm{MO}_{\mathrm{N}}-\mathrm{MO}_{\mathrm{D}}$ & $\mathrm{HO}_{\mathrm{N}}-\mathrm{HO}_{\mathrm{D}}$ \\
\hline Landbouw & 3,8 & $-7,6$ \\
Brandstof en energie & 24,1 & $-8,3$ \\
Ertsen en metalen & $-12,8$ & 3,0 \\
Mineralen & $-23,1$ & 0,3 \\
Chemie & $-13,7$ & 7,0 \\
Metaal & $-19,6$ & $-4,4$ \\
Land. en industr. machines & $-7,1$ & $-7,8$ \\
Kantoormachines & 16,1 & $-25,2$ \\
Electrotechniek & $-11,3$ & 3,3 \\
Transportmiddelen & $-14,2$ & $-5,5$ \\
Voeding & $-17,3$ & $-6,3$ \\
Textiel & $-15,9$ & $-1,5$ \\
Papier & $-17,7$ & $-2,9$ \\
Rubber en plastic & $-17,1$ & $-2,6$ \\
Overige industrie & $-29,0$ & $-7,0$ \\
Bouw & $-14,3$ & $-7,3$ \\
Handel, horeca en reparatie & $-16,7$ & $-2,9$ \\
Vervoer en communicatie & $-21,1$ & $-2,2$ \\
Banken en verzekeringen & $-13,9$ & 3,3 \\
\end{tabular}

${ }^{*} \mathrm{MO}, \mathrm{HO}=$ percentage werkenden met een middelbare respectievelijk hogere opleiding;

$\mathrm{N}=$ Nederland;

$\mathrm{D}=$ Duitsland

Bron: Eurostat, Labour Force Survey

Training van werkenden

Voor het adequaat in beeld brengen van de verschillen tussen het in de diverse bedrijfssectoren aanwezige menselijk kapitaal, is het van belang om naast de verschillen in het initiële opleidingsniveau van de werkenden ('recruteringsoptie') ook rekening te houden met de eventuele verschillen in de participatie van werkenden in trainingsactiviteiten ('trainingsoptie').

Helaas is de internationale vergelijkbaarheid van trainingsparticipatiecijfers gering (zie ook OECD, 1991). Bovendien zijn de beschikbare Eurostat data niet op basis van de in figuur 1 en 2 gehanteerde bedrijfsindeling te verbijzonderen. ${ }^{18}$ Desalniettemin is in figuur 3 getracht een indicatie te geven van de verschillen tussen Nederlandse en Duitse bedrijfstakken in het percentage werkenden dat recentelijk in trainingsactiviteiten heeft gepartici-

18. De gegevens zijn verbijzonderd op basis van de algemene NACE-classificatie. 
peerd. ${ }^{19}$ De cijfers hebben betrekking op het jaar 1990. Een positief percentage geeft daarbij aan dat in de desbetreffende Nederlandse bedrijfstak de trainingsparticipatie hoger is dan in dezelfde bedrijfstak in Duitsland.

Uit de figuur blijkt dat de verschillen in de trainingsparticipatie tussen Nederland en Duitsland afhankelijk zijn van het karakter van de training. Zo blijkt dat in Duitsland in alle bedrijfstakken de deelname aan het duale onderwijs groter is dan in Nederland. Overigens gaat het hier doorgaans om een vorm van initieel onderwijs (leerlingwezen, e.d.) die ook is meegenomen in de cijfers die ten grondslag liggen aan figuur 2. Daarbij zijn de verschillen met Nederland het grootst in de sectoren Handel, horeca en reparatie en het Bank- en verzekeringswezen, terwijl in de Landbouw het verschil het geringst is.

Daarentegen is in alle bedrijfstakken in Nederland de participatie in de overige trainingsactiviteiten hoger dan in Duitsland. Op dit punt zijn de verschillen het grootst in de sectoren Banken en verzekeringen, Energie en water en Handel, horeca en reparatie.

Figuur 3

Verschillen in trainingsparticipatie tussen Nederlandse en Duitse bedrijfstakken, 1990

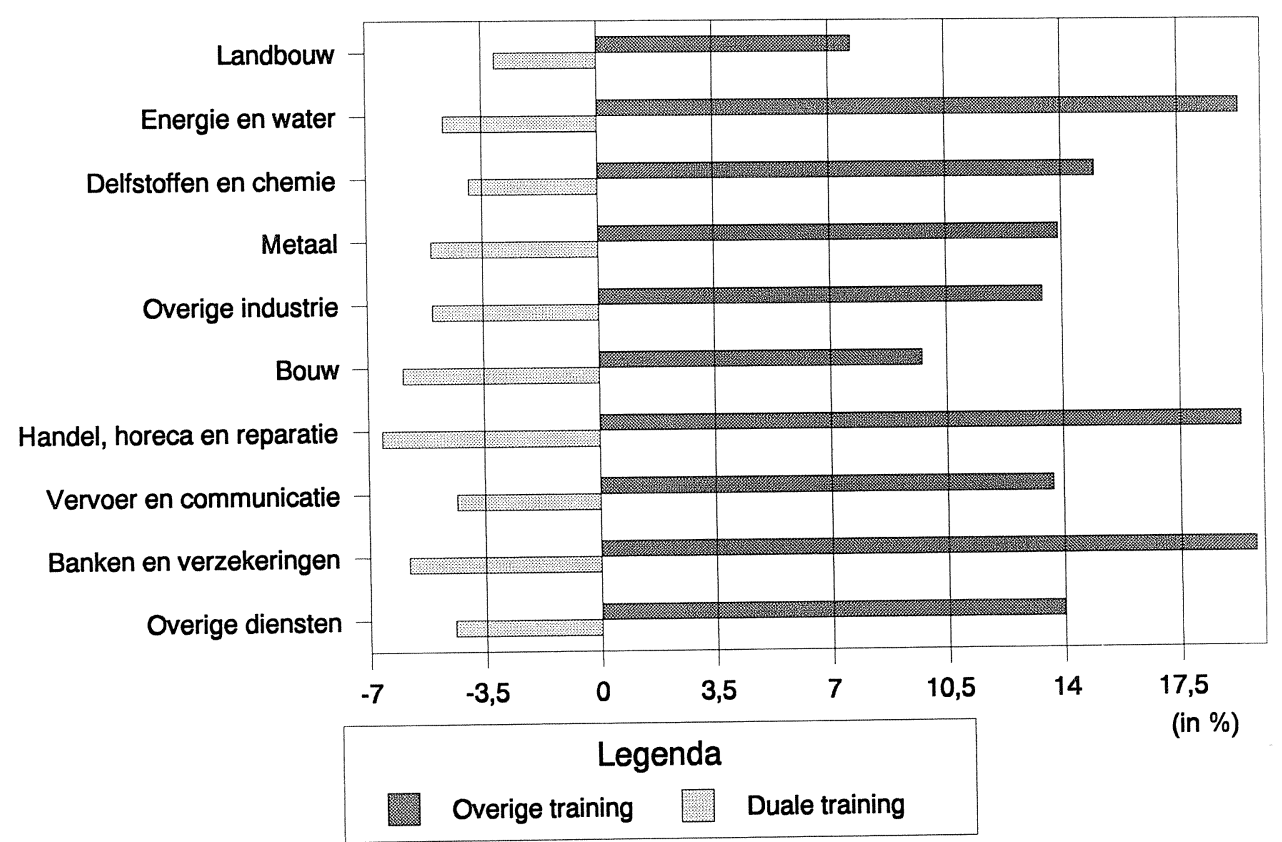

Bron: Eurostat, Labour Force Survey

19. Hierbij gaat het om het percentage werkenden dat in de vier weken voorafgaand aan de enquête een trainingsprogramma heeft gevolgd. 


\section{De betekenis van human capital voor de arbeidsproduktiviteit}

In deze paragraaf zal de relatie tussen human capital en arbeidsproduktiviteit nader worden geanalyseerd. Daarbij zullen achtereenvolgens regressievergelijkingen worden geschat met betrekking tot de bedrijfssectoren in Nederland en Duitsland ${ }^{20}$ en zal de relatieve arbeidsproduktiviteit in een bedrijfssector worden verklaard uit een vergelijking tussen beide landen. Op basis van de beschikbare gegevens is het helaas niet mogelijk naast het gevolgde initieel opleidingsniveau ook de deelname aan trainingsactiviteiten in de analyse op te nemen. Het initiële opleidingsniveau zal in de analyses niet, zoals in figuur 2, op basis van het gemiddelde opleidingsniveau van de werkenden worden gemodelleerd, maar op basis van de percentages werkenden met een middelbare opleiding (MO) en hoger onderwijs ( $\mathrm{HO}) .{ }^{21}$ Een dergelijke aanpak heeft als voordeel dat niet zonder meer verondersteld hoeft te worden dat er een lineair verband bestaat tussen het aantal jaren gevolgd onderwijs en de arbeidsproduktivieit, maar dat ook rekening kan worden gehouden met de specifieke betekenis van een adequaat aanbod van middelbaar en hoger geschoolden voor de arbeidsproduktiviteit in een bedrijfssector, waarop in paragraaf 3 werd gewezen.

Naast human capital is ook de produktiefactor fysiek kapitaal in de analyses opgenomen. De Cobb-Douglas produktiefunctie in vergelijking (1) dient als uitgangspunt voor de te schatten regressievergelijkingen. ${ }^{22}$

$$
Y=e^{c+\beta_{1} M O+\beta_{2} H O} L^{1-\beta_{3}} K^{\beta_{3}}
$$

In vergelijking (1) is $Y$ de toegevoegde waarde per bedrijfssector, $L$ het totale aantal werkenden per bedrijfssector, $K$ de kapitaalgoederenvoorraad per bedrijfssector en $C$ een constante. Daarbij geven de B's de bijbehorende coëfficiënten weer. Voor elke bedrijfssector geldt dat $\mathrm{LO}+\mathrm{MO}+\mathrm{HO}=100 \%$, waarbij $\mathrm{LO}$ het percentage werkenden is met een lagere opleiding. De variabele LO wordt echter niet meegenomen in de analyse vanwege de multicollineariteit met $\mathrm{MO}$ en $\mathrm{HO}$. Bovendien duiden de variabelen $\mathrm{MO}$ en $\mathrm{HO}$ op de inzet van human capital in een bedrijfssector, naast de (fysieke) inzet van het totale

20. Wegens 'missing values' in de dataset worden de schattingen in tabel 2 en 3 uitgevoerd voor 14 van de 19 bedrijfssectoren die in tabel 1 zijn genoemd. De bedrijfssectoren Landbouw, Kantoormachines, Handel, horeca en reparatie, Vervoer en communicatie en Banken en verzekeringen zijn niet meegenomen in de schattingen.

21. De gebruikte gegevens hebben betrekking op het jaar 1990.

22. Zie De Koning c.s. (1990) voor een overzicht van diverse produktiefuncties met heterogene arbeid. Zie Davies en Caves (1983) en Daly (1986) voor een toelichting op de produktiefunctie die in dit paper is gebruikt. 
aantal werkenden $L$ per bedrijfssector.

De te schatten vergelijking wordt verkregen door de logaritme te nemen van de linker- en de rechterkant van vergelijking (1), vervolgens te delen door $\ln L$, en het resultaat te herschrijven als in vergelijking (2). ${ }^{23}$

$\ln (Y / L)=C+\beta_{1} M O+\beta_{2} H O+\beta_{3} \ln (K / L)$

In vergelijking (2) zijn de coëfficiënten $\beta_{j}$ van de verklarende variabelen te interpreteren als elasticiteiten: ze geven aan met hoeveel procent de arbeidsproduktiviteit stijgt als de inzet van een produktiefactor met één procent toeneemt. ${ }^{24}$ De toegevoegde waarde per werknemer in een bedrijfssector $(\mathrm{Y} / \mathrm{L})$ wordt hierna aangeduid als de arbeidsproduktiviteit (AP), terwijl voor de kapitaalgoederenvoorraad per werknemer in een bedrijfssector (K/L) twee alternatieve indicatoren gehanteerd worden: de kapitaalintensiteit $(k)$ en de gemiddelde bruto investeringen per werknemer (i). ${ }^{25}$

Tabel 2 geeft een overzicht van de resultaten van de OLS-schattingen van vergelijking (2) ter verklaring van de arbeidsproduktiviteit in Nederland en Duitsland. In het algemeen kan worden geconcludeerd dat de geschatte vergelijkingen een aanzienlijk deel van de variantie in de arbeidsproduktiviteit tussen bedrijfssectoren verklaren.

De beide vergelijkingen (3) en (4) voor Nederland blijken de hoogte van de arbeidsproduktiviteit in de onderscheiden sectoren goed te verklaren. De vergelijking met de investeringsvariabele levert de grootste gecorrigeerde $\mathrm{R}^{2}$ op. Uit de schattingsresultaten komt naar voren dat naast de significante variabelen voor fysiek kapitaal, alleen het percentage werkenden met een middelbaar opleidingsniveau een significant positieve invloed heeft op het arbeidsproduktiviteitsniveau. ${ }^{26}$ Uit de schattingsresultaten van de eerste vergelijking kan worden afgeleid dat in de Nederlandse bedrijfssectoren bij een 1\%-toename van het percentage werkenden met een middelbare (beroeps)opleiding de arbeidsproduktiviteit met

23. Vergelijking (2) heeft als bijkomend voordeel dat er gecorrigeerd wordt voor verschillen in absolute grootte tussen bedrijfssectoren.

24. Merk op dat de onderwijsvariabelen $\mathrm{MO}$ en $\mathrm{HO}$, die reeds betrekking hebben op percentages, niet zijn weergegeven in logaritmen.

25. De kapitaalintensiteit voor 1989 is geschat op basis van de kapitaalintensiteit voor 1986 en de bruto investeringen tot 1990 , omdat in de beschikbare dataset de gegevens van de vaste kapitaalgoederenvoorraad voor de jaren 1987 tot 1990 ontbraken (zie Orbon, 1994). De data voor de kapitaalvariabelen zijn afkomstig van Eurostat. Voor de berekeningswijze van de kapitaalgoederenvoorraad per bedrijfssector wordt verwezen naar Paccoud (1983).

26. Met een significante variabele wordt in dit paper een variabele bedoeld die significant is op $5 \%$-niveau. 
$1,3 \%$ stijgt. De toename bedraagt zelfs $1,7 \%$ in de tweede vergelijking. Daarentegen geven de schattingsresultaten geen indicatie van een produktiviteitsverhogend effect van het percentage hoger opgeleiden. Daarbij moet wel de kanttekening worden gemaakt dat multicollineariteit tussen het percentage hoger opgeleiden en het fysiek kapitaal een oorzaak kan zijn van deze insignificantie (zie paragraaf 2).

Tabel 2

Schattingsresultaten voor de arbeidsproduktiviteit in Nederland $\left(A P_{N}\right)$ en Duitsland $\left(A P_{D}\right), 1989$ *

\begin{tabular}{|c|c|c|c|c|c|c|c|}
\hline & C & MO & $\mathrm{HO}$ & $\ln \mathrm{k}$ & $\ln \mathrm{i}$ & $\bar{R}^{2}$ & $\mathrm{~F}$ \\
\hline (3) $\ln A P_{N}$ & $\begin{array}{c}1,76 \\
(5,00)\end{array}$ & $\begin{array}{c}0,013 \\
(2,37)\end{array}$ & $\begin{array}{c}0,002 \\
(0,29)\end{array}$ & $\begin{array}{c}0,32 \\
(3,21)\end{array}$ & - & 0,76 & 15,0 \\
\hline (4) In $A P_{N}$ & $\begin{array}{c}2,39 \\
(11,20)\end{array}$ & $\begin{array}{r}0,017 \\
(3,60)\end{array}$ & $\begin{array}{l}-0,010 \\
(-0,95)\end{array}$ & - & $\begin{array}{c}0,40 \\
(3,39)\end{array}$ & 0,78 & 16,1 \\
\hline (5) $\ln A P_{D}$ & $\begin{array}{c}0,87 \\
(1,35)\end{array}$ & $\begin{array}{r}0,019 \\
(1,52)\end{array}$ & $\begin{array}{r}0,034 \\
(4,48)\end{array}$ & $\begin{array}{c}0,27 \\
(5,65)\end{array}$ & $\begin{array}{l}- \\
-\end{array}$ & 0,85 & 24,8 \\
\hline (6) $\ln A P_{D}$ & $\begin{array}{c}1,30 \\
(2,62)\end{array}$ & $\begin{array}{r}0,028 \\
(3,10)\end{array}$ & $\begin{array}{c}0,023 \\
(3,68)\end{array}$ & $\begin{array}{l}- \\
-\end{array}$ & $\begin{array}{c}0,31 \\
(7,90)\end{array}$ & 0,91 & 45,3 \\
\hline
\end{tabular}



Voor Duitsland geeft de vergelijking met de investeringsvariabele (vergelijking 6) de hoogste gecorrigeerde $\mathrm{R}^{2}$. Ook voor Duitsland heeft de produktiefactor kapitaal in beide vergelijkingen ( 5 en 6 ) een significant positieve invloed op de arbeidsproduktiviteit van bedrijfssectoren. Deze invloed is voor Duitsland kleiner dan voor Nederland, hoewel niet significant kleiner. Daarentegen is de invloed van het aandeel middelbaar en hoger opgeleiden op de arbeidsproduktiviteit groter voor Duitsland dan voor Nederland. Drie van de vier coëfficiënten zijn bovendien significant. Indien het percentage middelbaar opgeleiden met één procent toeneemt stijgt de arbeidsproduktiviteit met respectievelijk 1,9 en $2,8 \%$. In de eerste vergelijking voor Duitsland is het effect van het percentage werkenden met een middelbare (beroeps)opleiding op de arbeidsproduktiviteit weliswaar groter dan in Nederland, maar is dit effect niet significant. Bovendien kan er geen significant verschil vastgesteld worden tussen de effecten in Nederland en Duitsland van het percentage middelbaar opgeleiden op de arbeidsproduktiviteit. Voorts blijkt uit tabel 2 dat indien het percentage hoger opgeleiden in Duitse bedrijfssectoren met één procent toeneemt, de 
arbeidsproduktiviteit stijgt met respectievelijk 3,4 en 2,3\%. Deze effecten van het percentage hoger opgeleiden op de arbeidsproduktiviteit liggen in Duitsland significant hoger dan in Nederland.

\section{Relatieve arbeidsproduktiviteit}

Gelet op de internationale concurrentiekracht van bedrijfssectoren is het interessant om de relatieve arbeidsproduktiviteit van Nederlandse ten opzichte van Duitse bedrijfssectoren te verklaren uit de verschillen in de aandelen van middelbaar en hoger opgeleiden, en de verschillen in de kapitaalintensiteit van de desbetreffende sector (zie bv. Daly, 1986). In tabel 2 geven de geschatte coëfficiënten aan hoe groot de effecten van deze variabelen op de arbeidsproduktiviteit zijn. Daaruit kan worden afgeleid voor welk percentage de aandelen middelbaar en hoger opgeleiden en de beide kapitaalvariabelen de relatieve arbeidsproduktiviteit kunnen verklaren. ${ }^{27}$ Voor de invloed van elk van de verklarende variabelen geldt dat er een onderscheid kan worden gemaakt tussen twee componenten die de relatieve arbeidsproduktiviteit verklaren. Enerzijds kan de relatieve arbeidsproduktiviteit verklaard worden door het verschil in de inzet van middelbaar en hoger opgeleiden en door het verschil in de kapitaalintensiteit of investeringsintensiteit. Anderzijds kan de relatieve arbeidsproduktiviteit verklaard worden door het verschil in de geschatte coëfficiënten (de geschatte $\beta^{\prime}$ 's en de geschatte constante uit tabel 2) tussen Nederland en Duitsland.

Tabel 3 geeft een overzicht van de verschillende effecten op de relatieve arbeidsproduktiviteit (RAP). ${ }^{28}$ In het algemeen is het verschil tussen de Nederlandse en Duitse arbeidsproduktiviteit (waarbij In RAP $=100 \%$ ) relatief klein ten opzichte van de achterliggende verklarende variabelen. Uit figuur 1 is gebleken dat de Nederlandse arbeidsproduktiviteit in de meeste bedrijfssectoren groter is dan de Duitse arbeidsproduktiviteit. De Nederlandse arbeidsproduktiviteit wordt ten opzichte van de Duitse arbeidsproduktiviteit vergroot door de constante factor. ${ }^{29}$ Aan de andere kant wordt de Nederlandse arbeidsproduktiviteit ten

27. Daarbij zijn in de geschatte vergelijkingen (3) $t / m(6)$ van tabel 2 de gemiddelde waarden van de variabelen ingevuld. Vervolgens zijn de vergelijkingen (3) en (5), respectievelijk (4) en (6), van elkaar afgetrokken.

28. De gepresenteerde resultaten in tabel 3 suggereren een te grote exactheid. Voor de berekening van de resultaten zijn namelijk ook de gemiddelde waarden van de insignificante variabelen van tabel 2 gebruikt.

29. Een sluitende verklaring voor de significant grotere contstante van Nederland ten opzichte van Duitsland is met de gebruikte data van dit paper niet te geven. Mogelijk kan de relatief hoge arbeidsproduktiviteit in Nederland verklaard worden door het opnemen van de trainingsparticipatie in de regressievergelijkingen. Andere variabelen dan de trainingsparticipatie zijn bv. de ondernemingsgrootte en de gebruikte technologie (zie o.a. Van Ark, 1993). 
opzichte van de Duitse arbeidsproduktiviteit verkleind door de inzet van middelbaar opgeleiden en hoger opgeleiden. Eerder is geconstateerd dat de coëfficiënten van de geschatte variabelen in Nederland en Duitsland voor het aandeel middelbaar opgeleiden per bedrijfssector en de beide kapitaalvariabelen niet significant van elkaar verschillen. Voor deze variabelen blijkt echter uit tabel 3 dat het belang van het verschil in coëfficienten tussen Nederland en Duitsland relatief groot is ten opzichte van het verschil in de inzet van middelbaar opgeleiden in het produktieproces of het verschil in kapitaal- en investeringsintensiteit tussen Nederland en Duitsland. ${ }^{30}$ Zoals verwacht geldt dit in nog sterkere mate voor het belang van het verschil in coëfficiënten van het aandeel hoger opgeleiden, aangezien deze coëfficiënten voor Nederland en Duitsland significant van elkaar verschillen.

Tabel 3

Effecten op de relatieve arbeidsproduktiviteit (RAP), Nederland (N) t.o.v. Duitsland (D), 1989*

\begin{tabular}{|c|c|c|}
\hline & $\%$ van $\ln$ RAP $^{1}$ & $\%$ van In RAP $^{2}$ \\
\hline$\overline{C_{N}-C_{D}}$ & $443 \%$ & $546 \%$ \\
\hline $\begin{array}{l}M O_{N}-M O_{D} \\
\text { verschil in aandelen } \\
\text { verschil in coëfficiënten }\end{array}$ & $\begin{array}{r}-240 \% \\
-90 \% \\
-150 \%\end{array}$ & $\begin{array}{r}-411 \% \\
-117 \% \\
-294 \%\end{array}$ \\
\hline $\begin{array}{l}\mathrm{HO}_{\mathrm{N}}-\mathrm{HO}_{\mathrm{D}} \\
\text { verschil in aandelen } \\
\text { verschil in coëfficiënten }\end{array}$ & $\begin{array}{r}-231 \% \\
-3 \% \\
-228 \%\end{array}$ & $\begin{array}{r}-220 \% \\
13 \% \\
-233 \%\end{array}$ \\
\hline $\begin{array}{l}\text { In } \mathrm{k}_{\mathrm{N}} / \mathrm{k}_{\mathrm{N}} \\
\text { verschil in intensiteit } \\
\text { verschil in coëfficiënten }\end{array}$ & $\begin{array}{r}128 \% \\
25 \% \\
103 \%\end{array}$ & - \\
\hline $\begin{array}{l}\text { In } \mathrm{i}_{N} / \mathrm{i}_{\mathrm{D}} \\
\text { verschil in intensiteit } \\
\text { verschil in coëfficiënten }\end{array}$ & - & $\begin{array}{r}185 \% \\
115 \% \\
69 \%\end{array}$ \\
\hline totaal & $100 \%$ & $100 \%$ \\
\hline
\end{tabular}

${ }^{*} \mathrm{RAP}=A P_{\mathrm{N}} / \mathrm{AP}$;

${ }^{1}$ op basis van vgl. (3) - (5);

2 op basis van vgl. (4) - (6)

30. Uit tabel 1 is gebleken dat het aandeel middelbaar opgeleiden in bijna alle bedrijfssectoren groter is voor Duitsland dan voor Nederland. Aan de andere kant is in 9 van de 14 bedrijfssectoren de kapitaalintensiteit in Nederland groter dan in Duitsland. In 12 van de 14 bedrijfssectoren is de investeringsintensiteit in Nederland groter dan in Duitsland. 


\section{Besluit}

De relevantie van human capital voor de concurrentiekracht van bedrijfssectoren volgt uit de Ricardiaanse handelstheorie en de human capital theorie. Uit de Ricardiaanse handelstheorie volgt dat de arbeidsproduktiviteit een geschikte indicator is om de concurrentiekracht van sectoren te meten. Voorts geeft de human capital theorie aan hoe de verschillen in arbeidsproduktiviteit en gebruikte produktietechniek verklaard kunnen worden uit verschillen in het aanwezige menselijke kapitaal. Als maatstaf voor de concurrentiekracht geldt in dit paper de gemiddelde arbeidsproduktiviteit per bedrijfssector. Human capital kan worden opgebouwd door te investeren in initieel onderwijs of training. Voorts is aangegeven dat er vier effecten zijn van human capital die de arbeidsproduktiviteit kunnen verhogen, n.l. het werknemers-effect, het allocatie-effect, het diffusie-effect en het research-effect.

Indien Nederlandse en Duitse industriële bedrijfssectoren met elkaar worden vergeleken op basis van hun gemiddelde arbeidsproduktiviteit en investeringen in human capital, dan blijkt dat Nederland in de meeste sektoren een concurrentievoordeel heeft. Daarentegen blijft het gemiddelde opleidingsniveau van de Nederlandse werknemers achter bij dat van hun Duitse collega's. Het laatste is niet alleen te wijten aan de relatief kortere nominale opleidingsduur van middelbaar en hoger opgeleiden in Nederland, maar vooral ook aan het relatief kleine aandeel van middelbaar en hoger opgeleide werknemers in de totale werkgelegenheid in de Nederlandse bedrijfssektoren. Er lijkt hier spake te zijn van een paradox, omdat Duitse werknemers gemiddeld beter zijn opgeleid dan de Nederlandse werknemers, terwijl de gemiddelde arbeidsproduktiviteit achterblijft bij die van hun Nederlandse collega's.

Uit de empirische analyse van dit paper volgen twee mogelijke verklaringen voor deze paradox. Ten eerste is de trainingsparticipatie van werknemers die niet onder een vorm van duale training vallen, aanzienlijk hoger in de Nederlandse dan in de Duitse sectoren. Zoals opgemerkt hebben ook investeringen in training de eerder genoemde human-capital effecten op de produktiviteit. Helaas kon de trainingsparticipatie van werknemers niet als onafhankelijke variabele worden meegenomen bij de verklaring van de gemiddelde arbeidsproduktiviteit. Ten tweede is de kapitaalintensiteit van de Nederlandse bedrijfssectoren groter dan die van de Duitse bedrijfssectoren (zie voetnoten 25 en 30). Uit de schattingsresultaten blijkt dat de kapitaalintensiteit een significant positieve invloed heeft op de gemiddelde arbeidsproduktiviteit van bedrijfssectoren. Deze invloed is in Nederlandse bedrijfssectoren niet significant groter dan in Duitse bedrijfssectoren.

Aan de andere kant zijn in Duitsland niet alleen de percentages middelbaar en hoger 
opgeleiden per bedrijfssector in het algemeen groter dan in Nederland, maar zijn ook de effecten van de inzet van dit menselijk kapitaal op de gemiddelde arbeidsproduktiviteit groter. Het effect van het percentage middelbaar opgeleiden per bedrijfssector is voor Duitsland echter niet significant groter dan voor Nederland. Daarentegen is het effect van het percentage hoger opgeleiden per bedrijfssector voor Duitsland wel significant groter dan voor Nederland. Voorts is er voor Nederlandse bedrijfssectoren geen significant effect vastgesteld van het percentage hoger opgeleiden op de arbeidsproduktiviteit.

Uit het bovenstaande kan worden geconcludeerd dat Nederlandse sectoren vooral concurreren op basis van de inzet van fysiek kapitaal (en mogelijk ook training), terwijl Duitse sectoren dit vooral doen op basis van de inzet van menselijk kapitaal (d.w.z. investeringen in onderwijs). Voorts volgt uit de empirische analyse dat een versterking van de Nederlandse concurrentiekracht middels een verhoging van de arbeidsproduktiviteit mogelijk is door het aandeel middelbaar opgeleiden in de totale werkgelegenheid per bedrijfssector te vergroten. Immers, het percentage middelbaar opgeleiden per bedrijfssector is in Nederland aanzienlijk kleiner dan in Duitsland, terwijl er een positief effect van het percentage middelbaar opgeleiden op de Nederlandse arbeidsproduktiviteit is vastgesteld. Anderzijds is ook het percentage hoger opgeleiden per bedrijfssector in Nederland aanzienlijk kleiner dan in Nederland, hoewel er geen positief significant effect op de Nederlandse arbeidsproduktiviteit is vastgesteld. Toch kan het relatief lage aandeel hoger opgeleiden in de totale werkgelegenheid van Nederlandse bedrijfssectoren zorgelijk genoemd worden, vooral omdat hoger opgeleiden onmisbaar zijn voor research en development en voor de diffusie van nieuwe technologieën. Research en development en de diffusie van nieuwe technologieën dragen ertoe bij dat de concurrentiekracht op langere termijn wordt veilig gesteld (zie bv. Soete en Verspagen, 1993).

Nederlandse bedrijfssectoren lijken echter op langere termijn kwetsbaar te zijn in hun sterke concurrentiepositie, omdat hun concurrentiekracht gebaseerd is op een relatief hoge kapitaalintensiteit gecombineerd met een relatief grote inzet van laaggeschoolde arbeidskrachten. Juist de produktiefactor fysiek kapitaal is internationaal mobiel, en kan zich betrekkelijk eenvoudig verplaatsen naar landen waarin laaggeschoolde arbeidskrachten veel goedkoper zijn dan in Nederland. Daarentegen is de produktiefactor menselijk kapitaal 'opgeslagen' in de werknemers, die in het algemeen veel minder mobiel zijn. Dit betekent dat investeringen in onderwijs niet alleen de Nederlandse concurrentiekracht kunnen vergroten, maar ook de kwetsbaarheid van de Nederlandse concurrentiepositie kunnen verminderen. 


\section{Literatuur}

Ark, B. van (1993), International Comparisons of Output and Productivity, Manufacturing Produc tivity Performance of Ten Countries from 1950 to 1990, proefschrift, Groningen Growth and Development Centre, Monograph Series, nr. 1.

Barron, J.M., D.A. Black en M.A. Loewenstein (1989), Job Matching and On-the-job Training, Journal of Labor Economics, vol. 7, nr. 1, blz. 1-19.

Bartel, A.P. (1991), Productivity Gains form the Implementation of Employee Training Programs, NBER, Working Paper, nr. 3893.

Bartel, A.P. en F.R. Lichtenberg (1987), The Comparative Advantage of Implementing New Technology, Review of Economics and Statistics, vol. 69, nr. 1, blz. 1-11.

Becker, G.S. (1975), Human capital, A theoretical and empirical analysis, with special reference to education, tweede editie, Chicago/London.

Berendsen, H., A. de Grip en E.J.T.A. Willems (1991), De Arbeidsmarkt voor Onderzoekers 19902010, Ministerie van Economische Zaken, Beleidsstudies Technologie Economie, nr. 13, Den Haag.

Bishop, J.H. (1991), On-The-Job Training of New Hires, in: D. Stern and J.M.M. Ritzen (eds.), Market Failure in Training? New Economic Analysis and Evidence on Training of Adult Employees, Springer-Verlag, Berlin, Heidelberg.

Blaug, M. (1970), Introduction to the Economics of Education, Penguin Books, London.

Blaug, M. (1985), Where Are We Now in the Economics of Education?, Economics of Education Review, vol. 4, nr. 1, blz. 17-28.

Broer, D.P. en W.J. Jansen (1989), Employment, Schooling and Produktivity Growth, De Economist, vol. 137, nr. 4, blz. 425-453.

Butter, F. den, en F. Wollmer (1993), Endogene groei en technologie, Tijdschrift voor Politieke Ekonomie, vol. 16, nr. 2, blz. 56-71.

Cayseele, P. van (1990), Theorie van de Economische Groei, eerste uitgave, Acco Leuven.

CPB (1993), Het Nederlandse Onderwijs en Opleidingspeil in Internationaal Perspectief, werkdocument nr. 63, november, 's-Gravenhage.

Cörvers (1994), Human Capital Factors at the Firm Level, Working Paper 7E, Research Centrum voor Onderwijs en Arbeidsmarkt, Maastricht.

Cörvers (1994a), Human Capital, International Competitiveness and Trade Performance, Working Paper, Research Centrum voor Onderwijs en Arbeidsmarkt, Maastricht.

Daly, A. (1986), Education and Productivity: A Comparison of Great Britain and the United States, Britisch Journal of Industrial Relations, vol. 24, nr. 2, blz. 251-266.

Daly, A., D.M.W.N. Hitchens en K. Wagner (1985), Productivity, machinery and skills in a sample of British and German manufacturing plants, National Institute Economic Review, februari, blz. 84-97.

Davies, S.W. en R.E. Caves (1983), Inter-Industry Analysis of United Kingdom - United States Productivity Differences, N.I.E.S.R. Discussion Paper, nr. 63.

Dollar, D. (1993), Technological Differences as a Source of Comparative Advantage, American Economic Assocation Papers and Proceedings, vol. 83, nr. 2, blz. 431-435.

Dosi, G., K. Pavitt en L. Soete (1990), The Economics of Technical Change and International Trade, New York, Harvester Wheatsheaf.

Eurostat (1988), Labour Force Survey: Methods and definitions, Luxembourg. 
Gelderblom, A. and J. de Koning (1992), Meer-jarig, Minder-waardig? Een Onderzoek naar de Invloed van Leeftijd op Produktiviteit en Beloning, OSA-voorstudie V39.

Gelderblom, A. en J. de Koning (1994), Leren: Batig Investeren?, OSA-voorstudie, V41, Den Haag.

Groot, W. (1993a), Wage and Productivity Effects of Enterprise-related Training, Department of Economics, Leiden University.

Groot, W. (1993b), Overeducation and the Returns to Enterprise-related Schooling, Economics of Education Review, vol. 12, nr. 4, blz. 299-309.

Groot, L.F.M. and A. de Grip (1991), Technological Change and Skill Formation in the Bank Sector, Economics of Education Review, vol. 10, nr. 1, blz. 57-71.

Hashimoto, M. (1981), Firm-Specific Human Capital as a Shared Investment, American Economic Review, vol. 71, nr. 3, blz. 475-482.

Hebbink, G.E. (1992), Human Capital, Labor Demand and Wages: Aspects of Labor-Market Heterogeneity, Tinbergen Institute Research Series, nr. 35, Thesis Publishers, Amsterdam.

Hill, E.T. (1991), Post-Secondary Vocational Education and On-The-Job Training, Applied Economics, vol. 23, blz. 197-208.

Huffman, W.E. (1977), Allocative Efficiency: the Role of Human Capital, Quarterly Journal of Economics, vol. 91, blz. 59-80.

Jacobs, D., P. Boekholt en W. Zegveld (1990), De Economische Kracht van Nederland, TNOBeleidsstudies.

Koning, J. de, A. Gelderblom, M. Koss, R. Olieman (1990), Soorten Onderwijs en Economische Groei, Nederlands Economisch Instituut, Rotterdam.

Lockheed, M.E. (1987), Farmers' Education and Economic Performance, in: Psacharopoulos, G. (ed.), Economics of Education: Research and Studies, Pergamon Press, Oxford, blz. 110-116.

Maglen, L.R. (1990), Challenging the Human Capital Orthodoxy: The Education-Productivity Link Re-examined, Economic Record, december, blz. 281-294

Mankiw, N.G., D. Romer, D.N. Weil (1992), A Contribution to the Empirics of Economic Growth, Quarterly Journal of Economics, vol. 107, mei.

Mincer, J. (1974), Schooling, Experience, and Earnings, NBER, Columbia University Press, New York and London.

Ministerie van Economische Zaken (1990), Economie met Open Grenzen, Tweede Kamer, vergaderjaar 1989-1990, 21670, nrs. 1-2, Den Haag.

Ministerie van Economische Zaken (1993), Concurreren met Kennis, SDU Uitgeverij, Den Haag.

Nelson, R.R. en E.S. Phelps (1966), Investment in Human Capital, Technological Diffusion, and Economic Growth, American Economic Review, vol. 65, nr. 2, blz. 69-75.

NOWT (1994), Wetenschaps- en Technologie-Indicatoren 1994, CWTS R.U. Leiden en MERIT R.U. Limburg.

OECD (1986), R\&D, Invention and Competitiveness, Science and Technology Indicators, nr. 2.

OECD (1991), Employment Outlook 1991, Paris.

Orbon, J.P. (1994), Human capital en internationale concurrentiekracht: een analyse op mesoniveau, afstudeerscriptie, Rijksuniversiteit Limburg, Maastricht.

Paccoud, T. (1983), Le stock de capital fixe industriel dans les pays de la communauté européen ne: vers une comparabilité accrue, Eurostat, october.

Pencavel, J. (1991), Higher Education, Productivity, and Earnings: A Review, Journal of Economic Education, najaar, blz. 331-359. 
Porter, M. (1990), The Competitive Advantage of Nations, MacMillan, London.

Ram, R. (1980), Role of Education in Production: A Slightly New Approach, Quarterly Journal of Economics, vol. 94, blz. 365-373.

Romer, P.M. (1990), Endogenous Technological Change, Journal of Political Economy, vol. 98, nr. 5, blz. s71-s102.

Ryan, P. (1991; ed.), International Comparisons of Vocational Education and Training for Intermediate Skills, The Falmer Press, London.

Steedman en Wagner (1987), A second look at productivity, machinery and skills in Britain and Germany, National Institute Economic Review, november, blz. 84-97.

Soete, L. en B. Verspagen (1993), Onderwijs en onderzoek: voedingsbodem voor groei, Economisch Statistische Berichten, vol. 78, januari, nr. 3929, blz. 876-879.

Thurow, L.C. (1975), Generating Inequality, MacMillan, New York.

Verspagen, B. (1993), R\&D and productivity: A broad cross-section cross-country look, MERIT, nr. 93-007.

Welch, F. (1970), Education in Produktion, Journal of Political Economy, vol. 78, blz. 35-59.

Woodhall, M. (1987), Earnings and Education, in: Psacharopoulos, G. (ed.), Economics of Education: Research and Studies, Pergamon Press, Oxford, blz. 209-217.

Wozniak, G.D. (1987), Human Capital, Information, and the Early Adoption of New Technology, Journal of Human Resources, vol. 22, winter, blz. 101-112. 
